\title{
Glucokinase activator PSN-GK1 displays enhanced antihyperglycaemic and insulinotropic actions
}

\author{
M. C. T. Fyfe • J. R. White • A. Taylor • R. Chatfield • \\ E. Wargent $•$ R. L. Printz $\cdot$ T. Sulpice $\cdot$ \\ J. G. McCormack • M. J. Procter - C. Reynet • \\ P. S. Widdowson $\cdot$ P. Wong-Kai-In
}

Received: 16 January 2007 / Accepted: 2 February 2007 / Published online: 6 April 2007

(C) Springer-Verlag 2007

\begin{abstract}
Aims/hypothesis We evaluated the insulinotropic and antihyperglycaemic actions of glucokinase activators (GKAs), especially through acute and subchronic studies in rodent diabetes models with (2R)-2-(4-cyclopropanesulphonylphenyl)- $N$-(5-fluorothiazol-2-yl)-3-(tetrahydropyran-4-yl) propionamide (PSN-GK1), a novel and potent GKA. Materials and methods The action of PSN-GK1 on or in the following were investigated: (1) on human liver glucokinase, insulin secretion from MIN6 cells and 2deoxy-D- $\left[{ }^{3} \mathrm{H}\right]$ glucose $(2-\mathrm{DG})$ uptake into rat hepatocytes; and (2) in Zucker diabetic fatty rats and in non-diabetic $\mathrm{C} 57 \mathrm{Bl} / 6$, diabetic $d b / d b$ and $o b / o b$ mice.

Results At $5 \mathrm{mmol} / \mathrm{l}$ glucose, PSN-GK1 activated glucokinase (4.3-fold, median effective concentration [ $\left[\mathrm{EC}_{50}\right]$ $130 \mathrm{nmol} / \mathrm{l}$ ), increased MIN6 insulin secretion (26-fold, $\mathrm{EC}_{50} 267 \mathrm{nmol} / \mathrm{l}$ ) and 2-DG hepatocytic uptake (threefold,
\end{abstract}

M. C. T. Fyfe $(\bowtie) \cdot$ J. R. White $\cdot$ A. Taylor $\cdot$ R. Chatfield

J. G. McCormack · M. J. Procter · C. Reynet - P. S. Widdowson •

P. Wong-Kai-In

(OSI)Prosidion,

Windrush Court, Watlington Road,

Oxford OX4 6LT, UK

e-mail: mfyfe@prosidion.com

E. Wargent

The Clore Laboratory, University of Buckingham,

Buckingham, UK

\section{R. L. Printz}

Vanderbilt University School of Medicine, Vanderbilt University, Nashville, TN, USA

T. Sulpice

Physiogenex,

Toulouse, France
$\mathrm{EC}_{50} 1 \mu \mathrm{mol} / \mathrm{l}$ ); at higher glucose concentrations, $\mathrm{EC}_{50} \mathrm{~s}$ and fold-effectiveness were both lower. In C57B1/6 mice, PSN-GK1 reduced blood glucose at 1 and $10 \mathrm{mg} / \mathrm{kg}$ (by mouth), but insulin was increased significantly at only the higher dose. In hyperinsulinaemic 10-mmol/1 glucose clamps, PSN-GK1 increased 2-DG incorporation into liver glycogen sixfold, directly demonstrating liver effects. PSNGK1 improved glycaemic profiles in $d b / d b$ mice and Zucker diabetic fatty rats, diabetic animal models in which GKA efficacy has not previously been described, without causing hypoglycaemia. In $o b / o b$ mice, it dose-dependently reduced excursions in OGTTs. Moreover, after subchronic administration, no tachyphylaxis was evident and glycaemia was improved without alterations to lipid levels, liver weight, glycogen content or body weight.

Conclusions/interpretation PSN-GK1 was potently antihyperglycaemic through its effects on insulin release and hepatic glucose metabolism. It is one of the most potent GKAs described in the literature and is active in diabetic animal models where GKAs have not been reported to show efficacy to date. Ongoing human trials are investigating the potential of this novel therapeutic approach.

Keywords Diabetic animal models · Glucokinase · Glucokinase activator $\cdot$ Hepatic glucose uptake $\cdot$ Insulin secretion · Liver glycogen synthesis · Oral antihyperglycaemics $\cdot$ PSN-GK1

$\begin{array}{ll}\text { Abbreviations } \\ \text { 2-DG } & \text { 2-deoxy-D-- }\left[{ }^{3} \mathrm{H}\right] \text { glucose } \\ \text { EC }_{50} & \text { median effective concentration } \\ \text { G6PDH } & \text { glucose-6-phosphate dehydrogenase } \\ \text { GKA } & \text { glucokinase activator } \\ \text { GSIR } & \text { glucose-stimulated insulin release } \\ \text { GST } & \text { glutathione } S \text {-transferase }\end{array}$


PSN- (2R)-2-(4-cyclopropanesulphonylphenyl)- $N$ -

GK1 (5-fluorothiazol-2-yl)-3-(tetrahydropyran-4-yl) propionamide

$S_{0.5} \quad$ substrate concentration at half maximal velocity

$V_{\max } \quad$ maximal velocity

ZDF Zucker diabetic fatty

\section{Introduction}

The incidence of type 2 diabetes is increasing dramatically worldwide, largely due to the ongoing obesity epidemic. At present, no single agent is capable of achieving acceptable, long-lasting blood glucose control in the majority of patients [1]. Although combinations of available drugs can give superior glycaemic control [2], they tend to lose efficacy over time and produce unwanted side effects, such as weight gain. Thus, there is a pressing need for safe, novel drugs with improved efficacy [3].

Because of its key role in glucose homeostasis, glucokinase is a potential target for small-molecule type 2 diabetes therapeutics $[4,5]$. Its pivotal position in blood glucose control is determined by its actions in pancreas and liver [6], although it is expressed in numerous other cell types that complete the glucose-sensing network $[7,8]$. In beta cells, glucokinase is the glucose sensor that dictates the threshold for insulin secretion, while in hepatocytes it is rate-determining for glucose metabolism. Additionally, this enzyme plays a crucial role in neuronal glucosensing in the brain [9] and is also produced in incretin-releasing $\mathrm{K}$ and $\mathrm{L}$ cells in the gut [10], as well as in the pituitary [11]. Deactivating glucokinase mutations lead to maturity-onset diabetes of the young type 2 , a condition characterised by elevated plasma glucose resulting from glucokinase haploinsufficiency $[12,13]$. On the other hand, individuals with activating glucokinase mutations [14] have hyperinsulinaemic hypoglycaemia [15], a disorder attributed to a decreased threshold for glucose-stimulated insulin release (GSIR) and possibly also to elevated hepatic glucose use, although effects on liver glucokinase flux remain uninvestigated. The existence of patients with hyperinsulinaemic hypoglycaemia suggests that small-molecule glucokinase activators (GKAs) could exhibit powerful antihyperglycaemic properties both by augmenting GSIR and by altering hepatic glucose balance [16, 17]. Thus, GKAs could combine [18] the glucose-lowering effects of insulin secretagogues with biguanide-like, hepatic glucoselowering actions to provide enhanced glycaemic control.

Interest in glucokinase is intensifying [19] following the discovery of Ro-28-1675 [20]. This compound activates glucokinase by increasing affinity for glucose (substrate concentration at half maximal velocity, $S_{0.5}$ ) and maximal velocity $\left(V_{\max }\right)$. It enhances GSIR from isolated rat pancreatic islets, increases hepatocyte glucose uptake and demonstrates antihyperglycaemic effects in various rodent models. Moreover, chronic administration of Ro-28-1675 prevents the development of hyperglycaemia in dietinduced obese mice [21]. Like Ro-28-1675, other GKAs reported to date [22-25] bind an allosteric site found where the activating mutations cluster $[26,27]$.

Here, we evaluate the GKA (2R)-2-(4-cyclopropanesulphonylphenyl)- $N$-(5-fluorothiazol-2-yl)-3-(tetrahydropyran4-yl)propionamide (PSN-GK1) [28] (Fig. 1) and the translation of this compound's improved activity and excellent pharmacokinetic profile into potent acute and subchronic antihyperglycaemic effects in rodents. Impor-
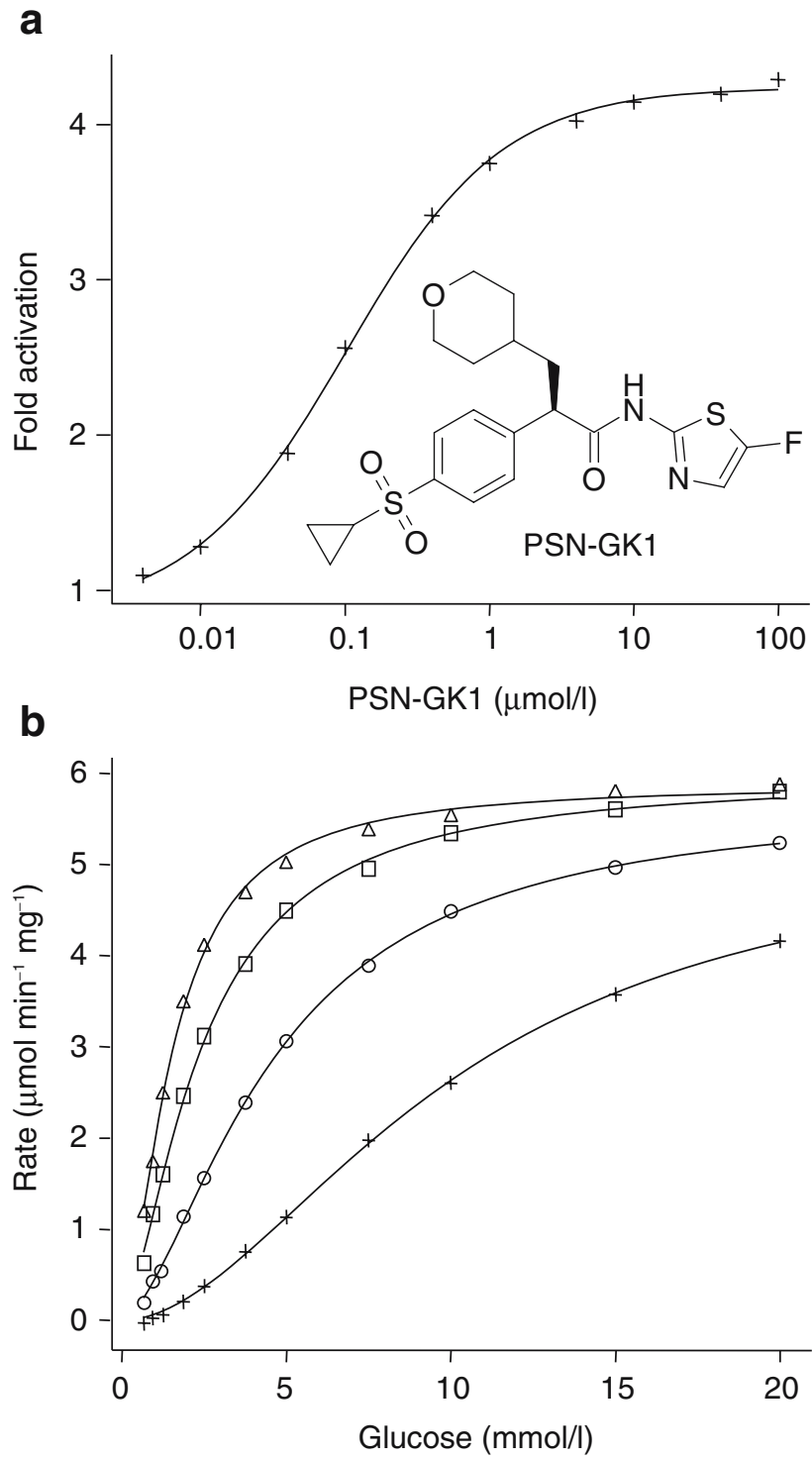

Fig. 1 In vitro activation of glucokinase by PSN-GK1. a Concentration-dependent activation of glucokinase by PSN-GK1 and structure of PSN-GK1. b Glucokinase kinetics with respect to glucose in the presence of different concentrations of PSN-GK1 ( $0.0 \mu \mathrm{mol} / 1$, crosses; $0.1 \mu \mathrm{mol} / 1$, circles; $0.4 \mu \mathrm{mol} / 1$, squares; $1.0 \mu \mathrm{mol} / 1$, triangles $)$ 
tantly, these antihyperglycaemic effects do not appear to be accompanied by adverse events, such as hypoglycaemia or hyperlipidaemia.

\section{Materials and methods}

Animals

Male C57Bl/6 (5-6 weeks), C57Bl/6 ob/ob (6-7 weeks) and female $\mathrm{C} 57 \mathrm{Bl} / \mathrm{KsJ} d b / d b$ (9 weeks) mice from Harlan Olac, Bicester, UK were housed under controlled conditions $\left(21 \pm 2{ }^{\circ} \mathrm{C} ; 45-65 \%\right.$ humidity; 12-h light-dark cycle, lights on $08.00 \mathrm{~h}$ ) with free access to rat and mouse no. 1 diet (Bantin and Kingman, Hull, UK). Female Zucker diabetic fatty (ZDF) rats (6 weeks old; Charles River, Manston, UK) were housed similarly, except that they were put on a 10/14-h light-dark cycle (lights off at $22.00 \mathrm{~h}$ ) and had free access to high-fat diet D1245 (Research Diets, New Brunswick, NJ, USA) (45\% of energy from fat) for 4 weeks prior to a meal-feeding regimen. For clamp studies, male C57Bl/6J mice (12 weeks) from Charles River were housed as above but fed pelleted chow (UAR, Nillemoison, France). Studies were approved by local ethical boards and animal husbandry and procedures carried out according to institutional guidelines.

\section{Materials}

PSN-GK1 was prepared [29], dissolved in DMSO and used in vitro at concentrations indicated with a final DMSO concentration of $\leq 5 \%$. For mice studies, PSN-GK1 was dissolved in warm 90\% water-10\% Gelucire 44/14 (Gattefossé, Gennevilliers, France), with stirring and/or sonication at $0.1-2.0 \mathrm{mg} / \mathrm{ml}$, for dosing at $1-20 \mathrm{mg} / \mathrm{kg}$ via oral gavage at $10 \mathrm{ml} / \mathrm{kg}$. For ZDF rats, PSN-GK1 was administered at $10 \mathrm{mg}^{2} \mathrm{ml}^{-1} \mathrm{~kg}^{-1}$ in warm $90 \%$ water-10\% Gelucire 44/14. Recombinant human hexokinases I, II and III and glucokinase (liver form) were expressed as glutathione $S$-transferase (GST) fusion proteins in $E$. coli, purified by glutathione affinity chromatography to $>98 \%$ purity and stored at $-80{ }^{\circ} \mathrm{C}$

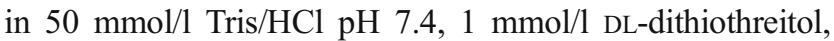
$50 \mathrm{mmol} / 1 \mathrm{NaCl}$ and $10 \%$ glycerol.

\section{Enzyme assays}

Glucokinase activity was measured in a coupled reaction with glucose-6-phosphate dehydrogenase (G6PDH) by monitoring NADPH production at $\mathrm{A}_{340}$ in a plate reader (SpectraMax 190; Molecular Devices, Wokingham, UK) after $15 \mathrm{~min}$ incubation at $24^{\circ} \mathrm{C}$, in a final volume of $100 \mu$ containing $25 \mathrm{mmol} / \mathrm{l} \mathrm{HEPES} \mathrm{pH} \mathrm{7.1,} 25 \mathrm{mmol} / 1 \mathrm{KCl}, 5 \mathrm{mmol} / 1$ glucose, $1 \mathrm{mmol} / \mathrm{l}$ ATP, $2 \mathrm{mmol} / \mathrm{l} \mathrm{MgCl}_{2}, 1 \mathrm{mmol} / 1 \mathrm{DL}$-dithiothreitol,
$1 \mathrm{mmol} / \mathrm{l} \mathrm{NADP}, 2.5 \mathrm{U} / \mathrm{ml}$ G6PDH, $0.4 \mu \mathrm{g}$ GST-glucokinase. These conditions were also used for hexokinases I to III, except that the glucose concentration was $0.25 \mathrm{mmol} / \mathrm{l}$. We tested ten dilutions of PSN-GK1 from 0.004 to $100 \mu \mathrm{mol} / 1$, calculating and fitting fold changes in activity vs controls to sigmoidal curves using a four-parameter logistic model. For effects on kinetic parameters $\left(S_{0.5}, V_{\max }\right.$, Hill coefficient), a series of velocity plots at different PSNGK1 and glucose concentrations (0.67-20 mmol/l) were fitted to the Hill equation using XLfit version 4.1 (IDBS, Guildford, UK).

\section{Cell incubations and assays}

MIN6 cells, a mouse pancreatic beta cell line, were cultured in DMEM containing $25 \mathrm{mmol} / 1$ glucose, $1 \mathrm{mmol} / 1$ sodium pyruvate, $50 \mu \mathrm{mol} / 1$ 2-mercaptoethanol, 15\% heat-inactivated FCS, $50 \mathrm{U} / \mathrm{ml}$ penicillin, $50 \mu \mathrm{g} / \mathrm{ml}$ streptomycin. Culture and incubations were at $37^{\circ} \mathrm{C}$. Cells were seeded at $4 \times 10^{5}$ cells per well in 12-well plates, cultured for 3 days, then washed twice with $\mathrm{KRB}$ containing $119 \mathrm{mmol} / \mathrm{l} \mathrm{NaCl}, 4.74 \mathrm{mmol} / \mathrm{l} \mathrm{KCl}$, $2.54 \mathrm{mmol} / 1 \mathrm{CaCl}_{2}, 1.19 \mathrm{mmol} / 1 \mathrm{MgSO}_{4}, 1.19 \mathrm{mmol} / \mathrm{l}$ $\mathrm{KH}_{2} \mathrm{PO}_{4}, 25 \mathrm{mmol} / \mathrm{l} \mathrm{NaHCO} 3,10 \mathrm{mmol} / \mathrm{l}$ HEPES $\mathrm{pH} 7.4$, $0.1 \% \mathrm{BSA}$ and $5 \mathrm{mmol} / \mathrm{l}$ glucose. Cells were pre-incubated for $1 \mathrm{~h}$ in KRB, followed by $1 \mathrm{~h}$ static incubations with PSNGK1 and glucose at indicated concentrations. Media samples were removed, cleared of debris by centrifugation at $1,000 \mathrm{~g}$ and insulin was measured in triplicate against standards using a rat insulin ELISA kit (Mercodia, Uppsala, Sweden). Cells were lysed in $150 \mathrm{mmol} / \mathrm{l} \mathrm{NaCl}, 1 \%$ glycerol, $1 \%$ Triton $\mathrm{X}-100$, $1 \mathrm{mmol} / 1$ EGTA, $50 \mathrm{mmol} / 1$ HEPES pH 7.5 supplemented with Complete Protease Inhibitor Cocktail (Roche Diagnostics, Penzberg, Germany) for protein measurement by bicinchoninic acid assay (Pierce, Rockford, IL, USA) with BSA standard.

Cryopreserved rat hepatocytes (XenoTech LLC, Lenexa, KS, USA) were centrifuged at $75 \mathrm{~g}$ over $25 \%$ Percoll and seeded at $2 \times 10^{5}$ to $4 \times 10^{5}$ cells per well in 12 -well plates coated with collagen-I. Cells were attached, cultured and assayed for 2-deoxy-D-[ $\left[{ }^{3} \mathrm{H}\right]$ glucose (2-DG) uptake as described [30]. Media contained $5.55 \mathrm{mmol} / 1$ glucose and after 2 days of culture cells were incubated for $4 \mathrm{~h}$ in fresh media containing $74 \mathrm{kBq} / \mathrm{ml}$ 2-DG (Perkin Elmer, Beaconsfield, UK). Cells were washed three times, lysed and portions of lysates used for scintillation counting and protein measurement as above. Net uptake was calculated as pmol 2-DG per $\mathrm{mg}$ protein and expressed as a percentage of the basal value.

Animal studies

C57Bl/6J mice Food was withdrawn $5 \mathrm{~h}$ before dosing, while water was available throughout. A blood sample was taken from the tail tip under local anaesthetic for glucose 
and insulin measurement. Thereafter, mice were weighed and dosed orally with PSN-GK1 (1 or $10 \mathrm{mg} / \mathrm{kg}$ ) or vehicle. Blood samples were taken 15, 30, 60, 120 and $240 \mathrm{~min}$ after dosing, samples $(20 \mu \mathrm{l})$ for glucose being taken into disposable micro-pipettes and added to $480 \mu \mathrm{l}$ haemolysis reagent. Duplicate $20-\mu \mathrm{l}$ aliquots haemolysed blood were added to $180 \mu \mathrm{l}$ Trinder's glucose reagent (Sigma enzymatic colorimetric method) in a 96-well plate. After mixing, samples were left (room temperature) for $30 \mathrm{~min}$ before reading against standards; correction was made for haemoglobin. Samples for insulin $(30 \mu \mathrm{l})$ were collected into heparin/Li-containing tubes, kept on ice for $<30 \mathrm{~min}$, centrifuged $\left(2,800 \mathrm{~g}, 10 \mathrm{~min}, 4^{\circ} \mathrm{C}\right)$ and stored at $-20^{\circ} \mathrm{C}$ for subsequent measurements using an insulin ELISA kit (Crystal Chem, Downers Grove, IL, USA) and SpectroMax 250 plate reader (Molecular Devices).

Hyperinsulinaemic-hyperglycaemic clamps After 8 days acclimatisation, during which mice were periodically handled, an indwelling catheter was placed into the femoral vein under anaesthesia, sealed under the back skin and glued on top of the skull. After 4 to 5 days, mice were fasted for $6 \mathrm{~h}$ before dosing and throughout the remainder of the study. PSN-GK1 $(10 \mathrm{mg} / \mathrm{kg})$ or vehicle was administered orally $30 \mathrm{~min}$ before $180 \mathrm{~min}$ i.v. infusion of a steady rate of $\left[{ }^{3} \mathrm{H}\right]$ glucose (to ensure detectable glucose isotopic dilution into blood and measurable incorporation into liver glycogen) and of pharmacological insulin at $18 \mathrm{mU} \mathrm{kg} \mathrm{min}^{-1}$. Non-radiolabelled glucose infusion maintained plasma glucose at $10 \mathrm{mmol} / \mathrm{l}$. Plasma glucose concentrations and $\left[{ }^{3} \mathrm{H}\right]$ glucose-specific activity were determined in $5 \mu \mathrm{l}$ blood from the tail tip every $10 \mathrm{~min}$ during the last hour. For glucose turnover, $\left[{ }^{3} \mathrm{H}\right]$ glucose enrichments were determined in deproteinised blood by $\mathrm{Zn}$ $(\mathrm{OH})_{2}$ precipitation; aliquots of the supernatant fraction were evaporated to dryness to determine radioactivity. In a second aliquot, glucose concentration was assessed by the glucose oxidase method. Plasma insulin was determined by ELISA (Mercodia) at study end to check that mice were stimulated comparably. Mice were killed by cervical dislocation. The liver glycogen synthesis rate was determined as described previously $[31,32]$ following extraction with $3 \%$ perchloric acid and precipitation with ethanol. The radioactive glycogen was counted and divided by the $\left[{ }^{3} \mathrm{H}\right]$ glucose-specific activity to determine the rate of synthesis.

C57Bl/KsJ db/db mice Blood $(20 \mu \mathrm{l})$ was obtained for glucose levels $45 \mathrm{~min}$ before dosing. Just prior to dosing, food was removed (free access to water), a further blood sample taken and mice dosed orally with PSN-GK1 $(20 \mathrm{mg} / \mathrm{kg})$ or vehicle, blood samples being removed 30,60,120, 180 and $300 \mathrm{~min}$ thereafter. Glucose was determined in whole blood as above.
$Z D F$ rats At age 10 to 11 weeks, rats were housed singly and fed high-fat diet $(45 \%$ energy from fat, D1245; Research Diets) as follows during the 14-h dark phase: (1) free access $(0-3 \mathrm{~h})$; (2) food removed $(3-7 \mathrm{~h})$; (3) $8 \mathrm{~g}(7-$ $14 \mathrm{~h}$ ). After 30 days, the diet was changed to one in which $60 \%$ of energy was from fat (D12492; Research Diets). Treatment commenced at age 14 to 15 weeks and was conducted as follows: $1 \mathrm{~h}$ before lights out, a blood sample was obtained from the tail tip under local anaesthesia for basal glucose. Thirty minutes later, rats were dosed orally with PSN-GK1 $(10 \mathrm{mg} / \mathrm{kg})$ or vehicle. At the start of the dark phase, blood samples were taken for glucose, then the animals were fed as described above with hourly glucose sampling.

OGTTS in ob/ob mice Food was withdrawn $5 \mathrm{~h}$ before OGTTs and throughout with free access to water provided. Blood $(20 \mu \mathrm{l})$ was removed for basal glucose $45 \mathrm{~min}$ before OGTTs. Then mice were weighed and dosed orally with PSN-GK1 $(3,5$ or $10 \mathrm{mg} / \mathrm{kg}$ ) or vehicle $30 \mathrm{~min}$ before glucose $(2 \mathrm{~g} / \mathrm{kg})$. Blood samples were taken 0, 30, 60, 90, 120, 180 and $240 \mathrm{~min}$ thereafter and glucose determined as above.

Subchronic study in ob/ob mice On day 0, $23.5 \mathrm{~h}$ before first dose, blood glucose was determined and mice allocated to groups. The day after, an OGTT was performed as above, with oral PSN-GK1 $(10 \mathrm{mg} / \mathrm{kg})$ or vehicle administered at $11.30 \mathrm{~h}, 30 \mathrm{~min}$ before the glucose load $(2 \mathrm{~g} / \mathrm{kg})$. After the OGTT, food was returned. PSN-GK1 or vehicle was dosed daily at $11.30 \mathrm{~h}$. On days 3 and 6 , glucose was measured in blood samples $15 \mathrm{~min}$ before and $60 \mathrm{~min}$ after dosing. Another OGTT was performed on day 8. On day 9, $3 \mathrm{~h}$ after dosing, terminal anaesthesia was induced and blood $(500-600 \mu \mathrm{l})$ collected via the abdominal aorta into heparin/Li-containing tubes and kept on ice ( $<30 \mathrm{~min})$, before centrifugation $\left(2,800 \mathrm{~g}, 10 \mathrm{~min}, 4^{\circ} \mathrm{C}\right)$ to give plasma $(\geq 300 \mu \mathrm{l})$, which was stored at $-20^{\circ} \mathrm{C}$ for subsequent analysis (using kits) of fructosamine (Randox, Crumlin, Northern Ireland, UK), NEFA (Wako, Neuss, Germany), triacylglycerol (Thermotrace, VIC, Australia) and alanine aminotransferase (Randox). Livers were removed, freezeclamped, weighed and stored (wrapped in foil) at $-80^{\circ} \mathrm{C}$ for subsequent glycogen analysis by ethanol precipitation after alkali digestion and for glucosyl measurement after amyloglucosidase treatment.

\section{Plasma PSN-GK1 concentrations}

A satellite exposure study, linked to basal blood glucoselowering/insulin secretion in C57B1/6 mice, was performed, in which 12 mice were dosed with $10 \mathrm{mg} / \mathrm{kg}$ PSN-GK1. Following terminal anaesthesia, blood $(500-600 \mu \mathrm{l})$ was 
collected from three animals via the abdominal aorta at 30 , 60,120 and $240 \mathrm{~min}$ after dosing. Blood was collected into heparin/Li-containing tubes and kept on ice $(<30 \mathrm{~min})$, before centrifugation $\left(2,800 \mathrm{~g}, 10 \mathrm{~min}, 4^{\circ} \mathrm{C}\right)$ and storage at $-20^{\circ} \mathrm{C}$ for subsequent compound measurement. A similar experiment was performed following a $5 \mathrm{mg} / \mathrm{kg}$ dose to $o b /$ $o b$ mice, with terminal blood collected after 30,60, 150 and $270 \mathrm{~min}$; these timepoints were used in a satellite exposure study paired with the OGTTs on days 1 and 8 (dosed daily) of the $o b / o b$ study above.

Aliquots $(50 \mu \mathrm{l})$ of plasma calibration standards, quality controls, unknown samples and blanks were placed into a 96-well protein precipitation plate (Argonaut Technologies, Hengoed, Wales, UK). The plate was placed on a vacuum manifold over a 96-well, 1-ml collection plate and acetonitrile $(200 \mu \mathrm{l})$ added to each well. The plate was left for precipitation to occur and supernatant fractions to drip through under gravity for $10 \mathrm{~min}$. Vacuum was applied and the block removed and centrifuged $(3,000 \mathrm{~g}, 10 \mathrm{~min})$ prior to injection on to a liquid chromatography/mass spectrometry/mass spectrometry system, comprising an HPLC column (Hichrom RPB; Highchrom, Theale, Berkshire, UK), $50 \times 2.1 \mathrm{~mm}$ column, mobile phase of acetonitrile$10 \mathrm{mmol} / 1$ ammonium formate, flow rate $0.25 \mathrm{ml} / \mathrm{min}$. The Micromass Quattro Micro spectrometer (Waters, Milford, MA, USA) was fitted with an electrospray ionisation interface. PSN-GK1 was detected by selected reaction monitoring of daughter ions in negative ion mode.

\section{Statistics}

Analyses consisted of one-way ANOVA coupled with $t$ tests. In cases where normality tests failed, the MannWhitney $U$ test was used.

\section{Results}

Glucokinase activation in vitro

PSN-GK1 raised the glucose phosphorylating activity of glucokinase at $5 \mathrm{mmol} / 1$ glucose by $4.3 \pm 0.2$-fold with an $\mathrm{EC}_{50}$ of $130 \pm 10 \mathrm{nmol} / \mathrm{l}$ (Fig. 1a); $54 \pm 6 \mathrm{nmol} / 1 \mathrm{PSN}-G K 1$ doubled activity. At $30 \mu \mathrm{mol} / \mathrm{l}, \mathrm{PSN}-\mathrm{GK} 1$ did not affect any of the related hexokinases. Glucokinase activation by PSNGK1 can be ascribed primarily to reduced glucose $S_{0.5}$ values (Fig. 1b, Table 1), with some modest increases in $V_{\max }$. Glucokinase kinetics for Mg-ATP were unaltered. The approximately sevenfold reduction in $S_{0.5}$ with $1 \mu \mathrm{mol} / 1$ PSN-GK1 corresponds to effects on the glucose cooperativity and reductions in Hill coefficient (Table 1). Effects of PSNGK1 on glucokinase resemble those of GKAs reported to bind at the proposed allosteric activator site $[26,27]$.

Actions in cells

Effects of PSN-GK1 on insulin secretion from MIN6 clonal mouse pancreatic beta cells [33] were measured at basal and raised glucose concentrations (Fig. 2a). Like pancreatic beta cells, these cells exclusively express the liver-type glucose transporter (GLUT2, also known as SLC2A2) [34], which allows normal glucose-sensing where glucose phosphorylation, not transport, is rate-limiting [35]. At $5 \mathrm{mmol} / \mathrm{l}$ glucose, PSN-GK1 increased secretion 25.9 \pm 5.3 -fold with an $\mathrm{EC}_{50}$ of $267 \pm 84 \mathrm{nmol} / \mathrm{l}$. It also produced stimulations above the effects of raised glucose at 10 and $15 \mathrm{mmol} / \mathrm{l}$. Although $\mathrm{EC}_{50} \mathrm{~s}$ were lower at higher glucose concentrations, corresponding fold increases were not as large.

Glucokinase exerts strong control over hepatic glucose metabolism and glycogen synthesis [36]. Hence, activation is expected to produce increases in glucose uptake/metabolism in cultured hepatocytes, which contain the high-capacity GLUT2 glucose transporter [37]. Effects of PSN-GK1 on 2-DG uptake in primary rat hepatocytes in $5.55 \mathrm{mmol} / \mathrm{l}$ glucose (Fig. 2b) were compared with those of sorbitol. Sorbitol activates glucokinase indirectly through its metabolite, fructose-1-phosphate, which promotes the enzyme's dissociation from its regulatory protein [38]. Relative to basal (100\%), PSN-GK1 enhanced uptake $300 \pm 34 \%$ with an $\mathrm{EC}_{50}$ of $1.04 \pm 0.05 \mu \mathrm{mol} / \mathrm{l}$, while the corresponding values for sorbitol were $137 \pm 9 \%$ and $34.8 \pm 6.7 \mu \mathrm{mol} / \mathrm{l}$. PSN-GK1 also increased uptake at $15 \mathrm{mmol} / \mathrm{l}$ glucose, but to a lesser degree (not shown).

Effects in non-diabetic mice

PSN-GK1 rapidly lowered basal blood glucose and increased insulin in non-diabetic C57Bl $/ 6$ mice at $10 \mathrm{mg} / \mathrm{kg}$

Table 1 Glucokinase kinetic parameters with respect to glucose at different concentrations of PSN-GK1

\begin{tabular}{|c|c|c|c|c|c|}
\hline PSN-GK1 $(\mu \mathrm{mol} / \mathrm{l})$ & $S_{0.5}(\mathrm{mmol} / \mathrm{l})$ & $S_{0.5}$ decrease (fold) & $V_{\max }\left(\mu \mathrm{mol} \min ^{-1} \mathrm{mg}^{-1}\right)$ & $V_{\max }$ increase (fold) & Hill coefficient \\
\hline 0.0 & 10.1 & - & 5.3 & - & 1.9 \\
\hline 0.1 & 4.6 & 2.2 & 5.7 & 1.1 & 1.6 \\
\hline 0.4 & 2.4 & 4.2 & 6.0 & 1.1 & 1.5 \\
\hline 1.0 & 1.5 & 6.7 & 5.9 & 1.1 & 1.6 \\
\hline
\end{tabular}


a
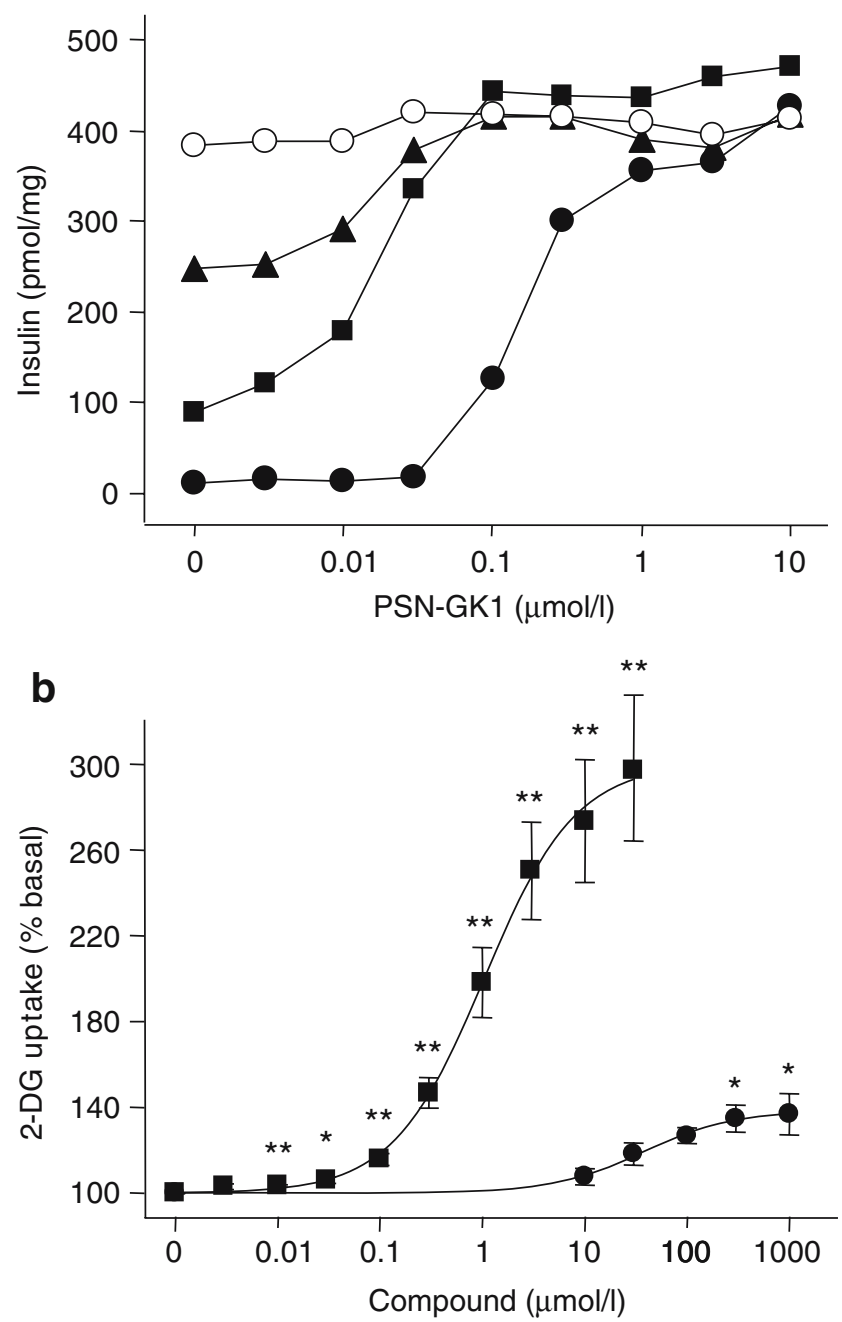

Fig. 2 Effects of PSN-GK1 on clonal pancreatic beta cells and cultured rat hepatocytes. a Insulin secretion in MIN6 pancreatic beta cells in the presence of glucose $(5 \mathrm{mmol} / 1$, closed circles; $10 \mathrm{mmol} / \mathrm{l}$, squares; $15 \mathrm{mmol} / 1$, triangles; $25 \mathrm{mmol} / 1$, open circles) and the indicated concentrations of PSN-GK1. Data are from a representative experiment of three repeat experiments. b 2-DG net uptake in cultured primary rat hepatocytes in the presence of $5.55 \mathrm{mmol} / 1$ glucose and the indicated concentrations of PSN-GK1 (squares) or sorbitol (circles). Results are mean \pm SEM of four independent experiments. ${ }^{*} p<0.05,{ }^{*} p<0.01$ vs basal 2-DG uptake. Average basal 2-DG uptake was 1.38 pmol 2-DG per mg cellular protein

(Fig. 3a,b), effects that were associated with good exposure (median PSN-GK1 concentration in $\mu \mathrm{mol} / 1, n=3$, at time points as specified: $30 \mathrm{~min}=11.7 ; 60 \mathrm{~min}=9.7 ; 120 \mathrm{~min}=$ 7.0; $240 \mathrm{~min}=4.1$ ). At a dose of $1 \mathrm{mg} / \mathrm{kg}$ PSN-GK1 also lowered glucose, but without altering insulin.

Effects of PSN-GK1 on liver glycogen biosynthesis were evaluated in a hyperinsulinaemic-hyperglycaemic clamp, with insulin at $18 \mathrm{mU} \mathrm{kg}^{-1} \mathrm{~min}^{-1}$ and glucose maintained at $10 \mathrm{mmol} / \mathrm{l}$, employing a radiolabelled glucose tracer to monitor incorporation into liver glycogen. Glucose infusion rates at 150 to $210 \mathrm{~min}$ after vehicle or $10 \mathrm{mg} / \mathrm{kg}$ PSN-GK1 were $124.9 \pm 4.8$ and $139.1 \pm 7.9 \mathrm{mg} \mathrm{kg}^{-1} \mathrm{~min}^{-1}$, respectively; at study end, plasma insulin values were $1,844 \pm 213$ and $1,803 \pm 239 \mathrm{pmol} / 1$, respectively. PSN-GK1 markedly raised the liver glycogen biosynthesis rate (Fig. 3c) $(5.41 \pm 1.40$; vehicle: $0.89 \pm 0.21 \mathrm{ng} \mathrm{g}$ tissue ${ }^{-1} \mathrm{~min}^{-1}, p<0.01$ ), a phenomenon attributed directly to liver glucokinase activation.
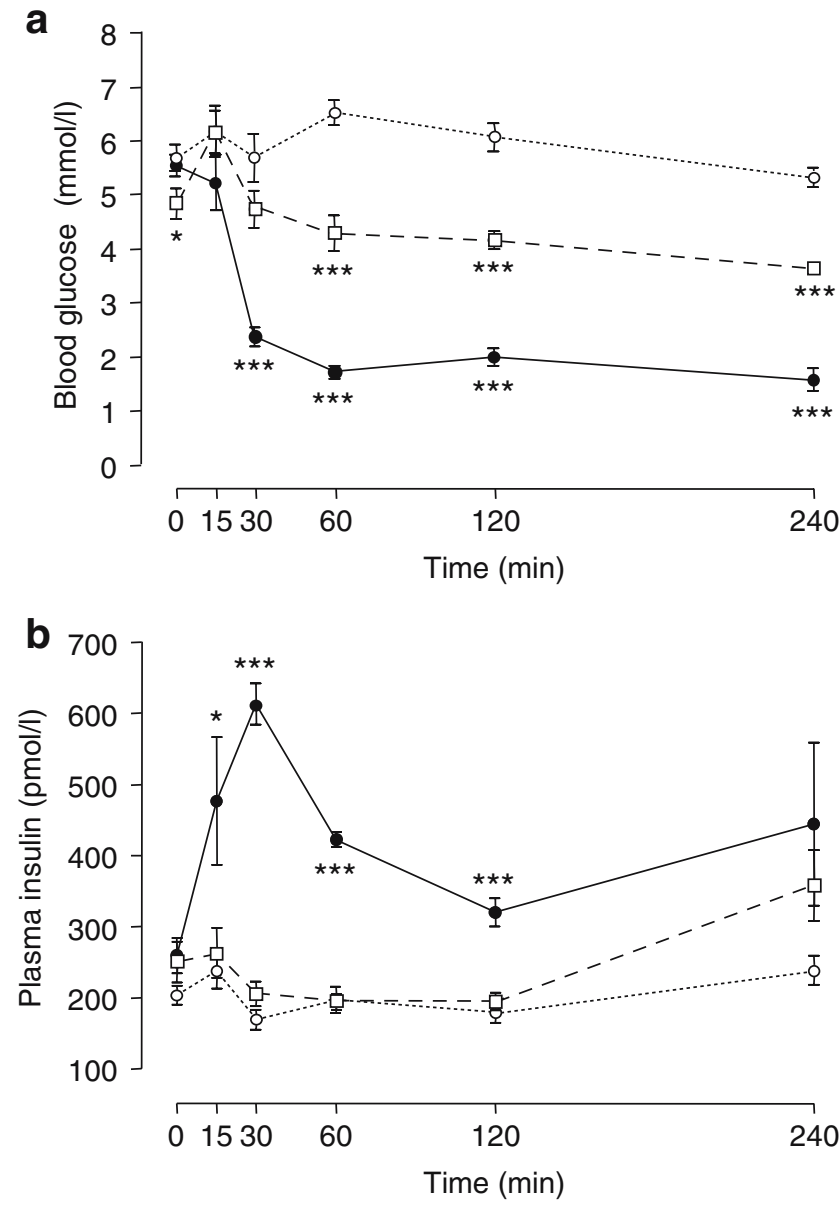

C

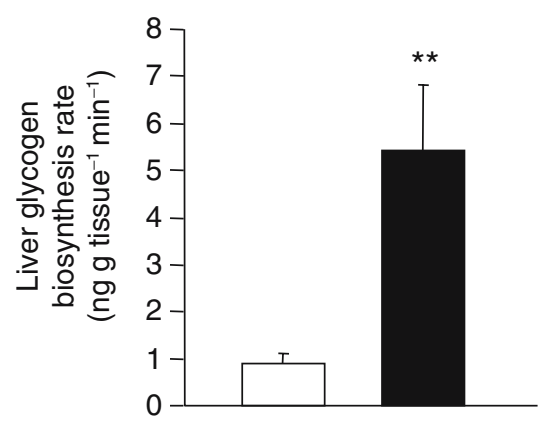

Fig. 3 PSN-GK1 lowers blood glucose levels through pancreatic and hepatic mechanisms. Blood glucose concentrations (a) and plasma insulin levels (b) following oral administration of vehicle (open circles) or PSN-GK1 (1 mg/kg, squares; $10 \mathrm{mg} / \mathrm{kg}$, closed circles) to 5-h-fasted male C57B1/6 mice. c Effect of vehicle (open bar) and PSN-GK1 $(10 \mathrm{mg} / \mathrm{kg}$ by mouth; black bar $)$ on liver glycogen biosynthesis rate under hyperinsulinaemic-hyperglycaemic conditions. ${ }^{*} p<0.05 ;{ }^{* *} p<0.01 ;{ }^{* * *} p<0.001$ vs vehicle control 


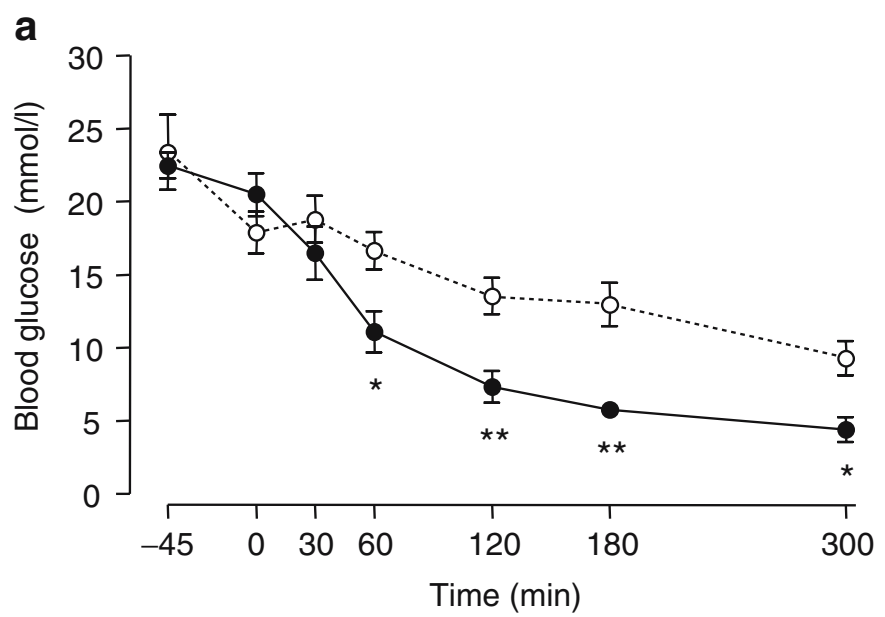

Fig. 4 PSN-GK1 (20 mg/kg by mouth; closed circles) attenuates hyperglycaemia compared with vehicle (open circles) in female $d b / d b$ mice. a Blood glucose profile. b Delta delta blood glucose $(\Delta \Delta \mathrm{BG})$ profiles reflecting the difference between the change in blood glucose concentrations from time $0 \mathrm{~min}$ within each experimental group $(\Delta \mathrm{BG})$

Effects in $d b / d b$ mice and ZDF rats

PSN-GK1 at $20 \mathrm{mg} / \mathrm{kg}$ produced rapid and significant antihyperglycaemia in fed (food removed immediately before dosing) $d b / d b$ mice, compared with controls (Fig. 4). After $180 \mathrm{~min}$, PSN-GK1 lowered blood glucose (from $20.5 \pm 1.5 \mathrm{mmol} / 1$ to $5.8 \pm 0.5 \mathrm{mmol} / \mathrm{l}$ ) compared with controls (from $17.9 \pm 1.4$ to $13.0 \pm 1.5 \mathrm{mmol} / \mathrm{l}$ ).

ZDF rats were trained to a two-meal paradigm to monitor effects on glucose control over multiple meals. Following a single $10 \mathrm{mg} / \mathrm{kg}$ dose, PSN-GK1 lowered glycaemia at all time points during both meals and at nearly all time points between (Fig. 5), indicating an extended duration of action; blood glucose was 3.3-4.8 mmol/1 and

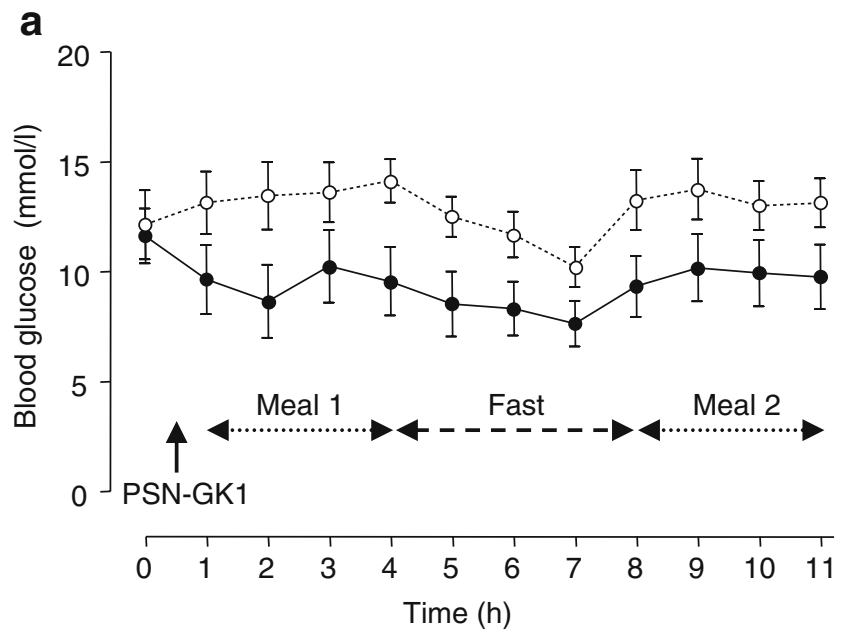

Fig. 5 The anti-hyperglycaemic effects of PSN-GK1 $(10 \mathrm{mg} / \mathrm{kg}$ by mouth; closed circles) compared with vehicle (open circles) endure over two distinct meals in female ZDF rats. a Blood glucose profile.

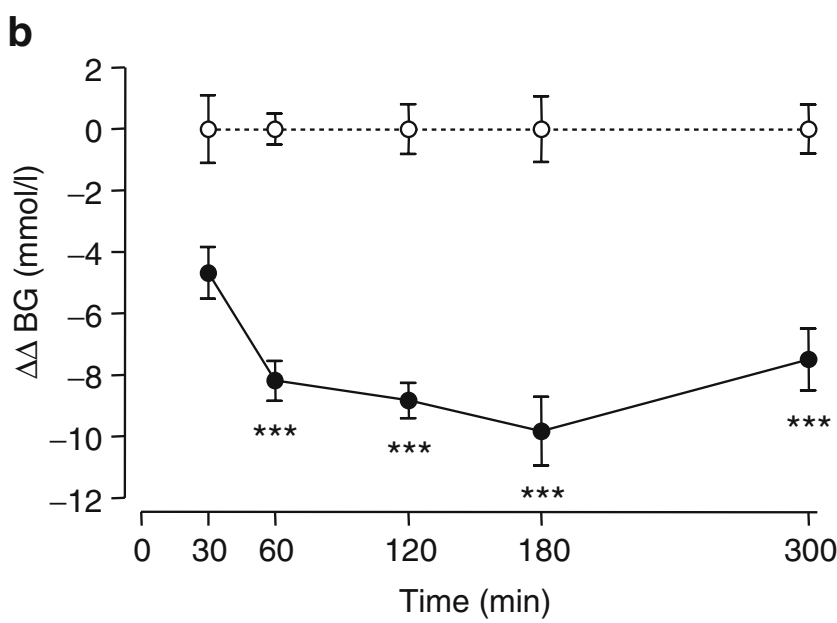

and the change in blood glucose concentrations from time $0 \mathrm{~min}$ in the vehicle-treated arm $\left(\Delta \mathrm{BG}_{\text {vehicle }}\right)$. Thus, $\Delta \Delta \mathrm{BG}=\Delta \mathrm{BG}-\Delta \mathrm{BG}_{\text {vehicle. }}{ }^{*} p<$ $0.05 ; * * p<0.01 ; * * * p<0.001$ vs vehicle control

3.4-4.0 mmol/1 lower than vehicle-treated counterparts during the first and second meals, respectively.

OGTTs and subchronic effects in $o b / o b$ mice

PSN-GK1 $(5 \mathrm{mg} / \mathrm{kg})$ improved glucose tolerance when administered $30 \mathrm{~min}$ before the glucose load (Fig. 6a). Glucose administration coincided with the PSN-GK1 maximum plasma concentration (median concentrations in $\mu \mathrm{mol} / 1, n=3$, at specified time points: $30 \mathrm{~min}=4.1 ; 60 \mathrm{~min}=$ $2.5 ; 150 \min =1.5 ; 270 \min =0.8)$. Effects were dosedependent, $10 \mathrm{mg} / \mathrm{kg}$ reducing glucose excursions to a greater degree than doses of 3 and $5 \mathrm{mg} / \mathrm{kg}$ (not shown).

PSN-GK1 $(10 \mathrm{mg} / \mathrm{kg})$ was dosed once daily for 9 days. Comparable antihyperglycaemic effects were observed in

b

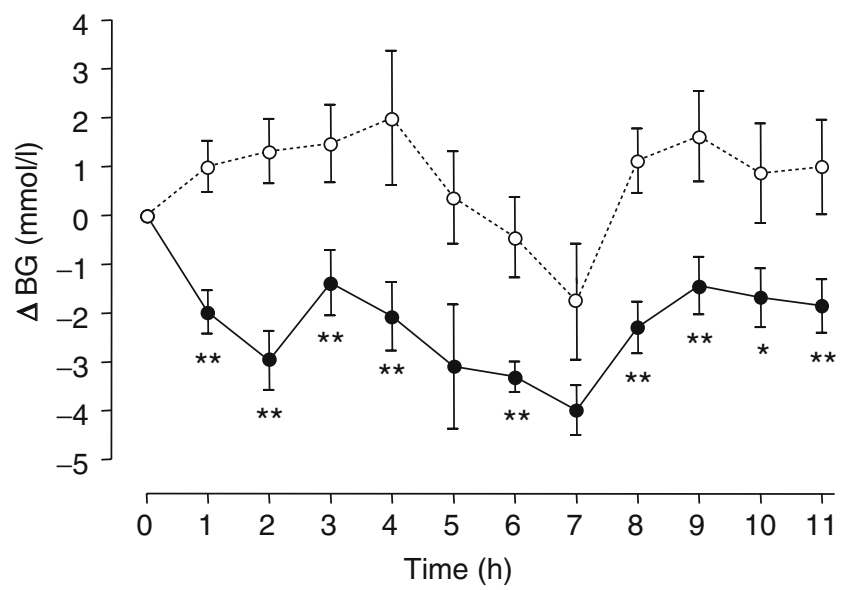

b Delta blood glucose values, which reflect the change in blood glucose from time 0 min within each experimental group, i.e. $\Delta \mathrm{BG}=$ $\mathrm{BG}_{\text {time }}-\mathrm{BG}_{0 \text { min. }}{ }^{*} p<0.05 ;{ }^{*} p<0.01$ vs vehicle control 


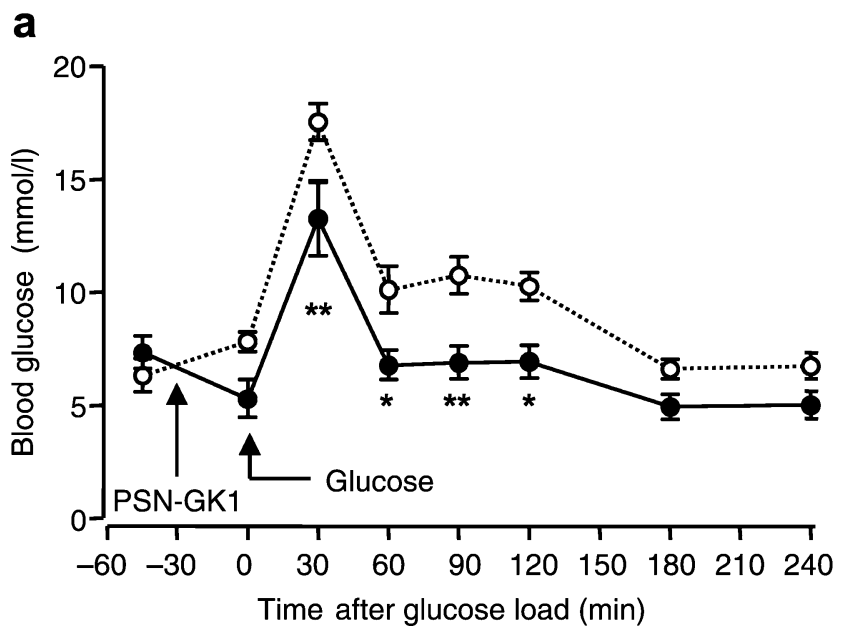

Fig. 6 PSN-GK1 attenuates hyperglycaemia subchronically in $o b / o b$ mice. a Blood glucose profile from an OGTT, in which PSN-GK1 $(5 \mathrm{mg} / \mathrm{kg}$ by mouth; closed circles) and vehicle (open circles) were administered orally to male $\mathrm{ob} / \mathrm{ob}$ mice $30 \mathrm{~min}$ prior to an oral glucose

OGTTs on days 1 and 8 , where compound exposures were similar (Table 2). PSN-GK1 improved glucose profiles throughout vs controls (Fig. 6b). After 9 days, there were no significant differences (Table 2) between PSN-GK1- and vehicle-treated groups in body weight, plasma lipids, liver b

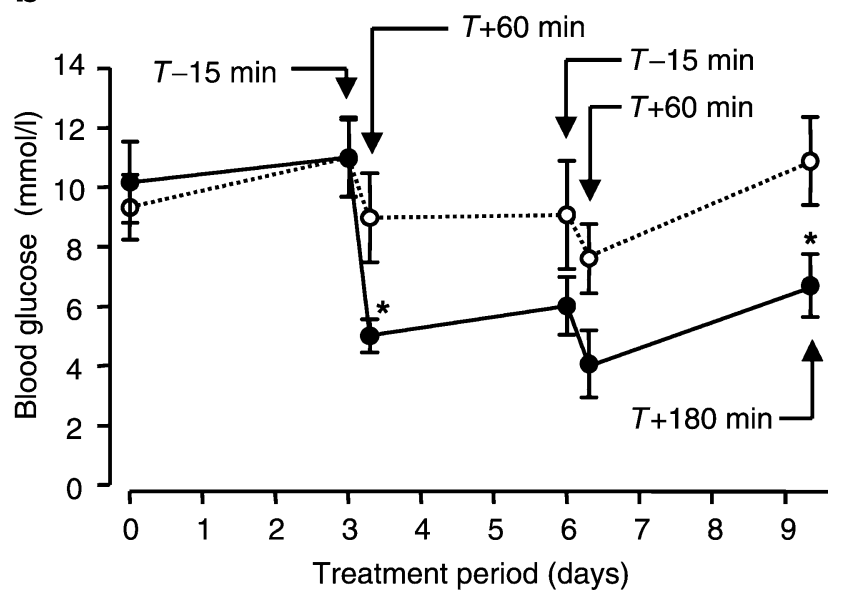

load $\left(2 \mathrm{~g} / \mathrm{kg}\right.$ ). b Effects of dosing $10 \mathrm{mg} \mathrm{kg}^{-1}$ day $^{-1}$ PSN-GK1 (closed circles) and vehicle (open circles) to male $o b / o b$ mice for nine consecutive days at $T=0$ min each day. ${ }^{*} p<0.05 ;{ }^{*} p<0.01$ vs vehicle control

weights, liver glycogen, liver function (alanine aminotransferase levels) or plasma fructosamine, an index of mediumto long-term glucose control; however, the study may have been too short to reveal fructosamine differences.

Table 2 Data from subchronic experiment in $o b / o b$ mice

Body weight (g)

Day 0

$31.4 \pm 1.2$

$35.2 \pm 1.3$

OGTT blood glucose AUC $(\mathrm{mmol} / 1 \times 120 \mathrm{~min})$

Day 1

Day 8

Day 1 median PSN-GK1 concentrations $(\mu \mathrm{mol} / \mathrm{l})$

At 30 min post-dose

At 60 min post-dose

At $150 \mathrm{~min}$ post-dose

At 270 min post-dose

Day 8 median PSN-GK1 concentrations $(\mu \mathrm{mol} / \mathrm{l})$

At $30 \mathrm{~min}$ post-dose

At 60 min post-dose

At $150 \mathrm{~min}$ post-dose

At 270 min post-dose

Day 9 plasma NEFA (mmol/l)

Day 9 plasma triacylglycerol $(\mathrm{mmol} / \mathrm{l})$

Day 9 plasma ALT (U/l)

Final liver weight $(\mathrm{g})$

Day 9 liver glycogen content

( $\mu$ mol glycosyl residues/g wet weight)

Plasma fructosamine (mmol/l)

$\begin{array}{ll}1,224 \pm 120 & 786 \pm 100 \\ 1,043 \pm 54 & 639 \pm 32^{* *} \\ - & \\ - & 11.8 \\ - & 7.1 \\ - & 3.6 \\ - & 1.7 \\ - & \\ - & 11.5 \\ - & 7.4 \\ - & 4.2 \\ 0.98 \pm 0.17 & 2.9 \\ 0.78 \pm 0.10 & 1.02 \pm 0.09 \\ 39.6 \pm 5.9 & 0.64 \pm 0.03 \\ 2.65 \pm 0.24 & 54.0 \pm 8.9 \\ 270 \pm 22 & 2.87 \pm 0.13 \\ & 234 \pm 33\end{array}$

$0.18 \pm 0.01$
$31.9 \pm 1.5$

$36.3 \pm 1.5$

$786 \pm 100$

$234 \pm 33$

$0.18 \pm 0.01$

Data are means $\pm \mathrm{SE}$ from six mice

$A L T$, alanine aminotransferase

$* * p<0.01$ vs vehicle control 


\section{Discussion}

PSN-GK1 is a potent activator of glucokinase in vitro, possessing enhanced activity relative to the archetypal GKA Ro-28-1675. At $5 \mathrm{mmol} / \mathrm{l}$ glucose, PSN-GK1 at $0.05 \mu \mathrm{mol} / 1$ doubles glucokinase activity, whereas $0.18 \mu \mathrm{mol} / 1$ Ro-28-1675 increases activity only by 1.5 -fold [21]. Although the recently disclosed GKA50 has an $\mathrm{EC}_{50}$ of $0.03 \mu \mathrm{mol} / 1$ [24, 39], no fold-activation data are available. Thus, PSN-GK1 is one of the most potent GKAs described to date. Like Ro-28-1675 and GKA50, PSN-GK1 principally increases catalytic effectiveness, expressed as the $V_{\text {max }}: S_{0.5}$ ratio, by lowering $S_{0.5}$, as indicated by the fact that $V_{\max }$ increases were modest. As expected, PSN-GK1 does not activate other hexokinases that do not possess glucokinase's allosteric activator site [26].

PSN-GK1 markedly increases GSIR from MIN6 cells, most notably at lower glucose concentrations, where basal secretion is lower. However, effects are also observed at 10 and $15 \mathrm{mmol} / \mathrm{l}$ glucose, values more typical of the diabetic condition. Here, concentration-responses for PSN-GK1 are left-shifted, suggesting that, at higher glucose concentrations, smaller doses would still provide maximum secretion. The fact that higher PSN-GK1 concentrations are required to stimulate secretion at lower glucose concentrations may provide GKAs with an inbuilt safety mechanism that glucose-insensitive sulfonylureas [40] do not have. At $25 \mathrm{mmol} / \mathrm{l}$ glucose, PSN-GK1 does not augment secretion, consistent with a mechanism chiefly involving reduction in $S_{0.5}$ rather than increased $V_{\max }$.

The antihyperglycaemic properties of GKAs may also be mediated through enhanced hepatic glucose utilisation, so that activation will cause increases in uptake of glucose or other glucokinase substrates, such as non-metabolisable 2DG. Glucokinase activation in hepatocytes, either pharmacologically or by adenoviral overexpression, results in increased 2-DG uptake [22, 30]. Stimulation of hepatic glucose phosphorylation by sorbitol, a precursor to the indirect GKA fructose-1-phosphate [38], has been reported with an $\mathrm{EC}_{50}$ of $20-30 \mu \mathrm{mol} / 1$ and stimulation of $\sim 1.5$-fold [41], values similar to those seen in our hands in rat primary hepatocytes. PSN-GK1 has a substantially greater effect on 2-DG uptake, indicating that glucokinase activation occurs by a different mechanism.

In vitro effects in pancreatic and hepatic cells are translated in vivo in non-diabetic mice, where PSN-GK1 stimulated insulin secretion, reduced blood glucose and raised liver glycogen biosynthesis. The increased potency of PSN-GK1 compared with Ro-28-1675 is evident in this model: $15 \mathrm{mg} / \mathrm{kg}$ Ro-28-1675 maximally raised insulin $\sim 1.5$-fold [21], while $10 \mathrm{mg} / \mathrm{kg}$ PSN-GK1 induced an approx. threefold increase. As mentioned, the hypoglycaemia provoked by GKAs in a non-diabetic setting may be more manageable than that resulting from sulfonylureas [40] because the glucose-lowering effected by GKAs is glucose-dependent $[42,43]$. At $1 \mathrm{mg} / \mathrm{kg}$, PSN-GK1 reduced blood glucose without hypoglycaemia, indicating that there is a reasonable window between glucose-lowering and severe hypoglycaemia. At this dose, no effects on insulin secretion were apparent, indicating that severe hypoglycaemic actions may be associated with insulinotropic effects. However, the fact that this dose was able to decrease blood glucose possibly indicates a hepatic action, although insulin levels were raised in view of the prevailing low glucose. Hyperinsulinaemic-hyperglycaemic clamps directly confirmed the hepatic contribution (Fig. 3c).

To date, there have been no reports of GKAs displaying antihyperglycaemic actions in $d b / d b$ mice. Indeed, some GKAs, such as Ro-28-1675, lose their effectiveness in older $d b / d b$ mice with blood glucose $\sim 16.7 \mathrm{mmol} / 1$ and hypoinsulinaemia [20]. In our study, by contrast, PSN-GK1 normalised blood glucose in $d b / d b$ mice with initial blood glucose $>20 \mathrm{mmol} / 1$ without hypoglycaemia. The potential of GKAs to control blood glucose is underscored by the fact that a single dose of PSN-GK1 can elicit antihyperglycaemic effects in high-fat-diet-fed female ZDF rats over multiple 'meals' and an extended time period without hypoglycaemia. To our knowledge, PSN-GK1 is the first GKA to show efficacy in this model.

PSN-GK1 improved glucose tolerance dose-dependently in $o b / o b$ mice, again without hypoglycaemia. Like Ro-28-1675, PSN-GK1 appears to normalise blood glucose in rodent type 2 diabetes models, even though it produces hypoglycaemia in non-diabetic animals. It has been postulated [21] that GKAs do not provoke hypoglycaemia in diabetic rodents because of underlying defects in glucose homeostasis. The results seen acutely in OGTTs translate into subchronic efficacy, comparable antihyperglycaemic actions being noted at the beginning and end of the 9-day experiment, i.e. PSNGK1's effects did not appear to suffer from tachyphylaxis. Moreover, although PSN-GK1 improved blood glucose throughout this study, it did not alter liver glycogen, suggesting that GKAs lower blood glucose principally by a mechanism unrelated to increased glycogen storage.

One concern with GKAs is the possibility that they could increase lipid levels. In normal rodents, chronic glucokinase overexpression leads to raised hepatic lipogenesis and circulating lipids [44, 45]. However, humans with activating glucokinase mutations have normal lipids [15], hinting that long-term glucokinase activation may not produce adverse lipid effects. Effects of other GKAs on lipids following repeated administration have not been described. In our study, subchronic administration of PSNGK1 did not affect plasma lipids, indicating that concerns surrounding GKAs and increased lipogenesis may be unfounded. However, longer term studies will be required 
ultimately to ensure that GKAs are safe in this regard. It was also discovered that PSN-GK1 did not induce changes in liver weight or plasma alanine aminotransferase, an indicator of liver toxicity and steatosis.

In summary, we have demonstrated that PSN-GK1's ability to activate glucokinase results in robust hypoglycaemic effects in normal mice and antihyperglycaemic actions in diabetic rodents. The overall efficacy, plus the fact that no adverse events were observed subchronically, further supports the premise that GKAs may be among the next generation of oral glucose-lowering therapies. In contrast to current therapies that target a single organ, e.g. sulfonylureas (pancreas) or metformin (liver), GKAs could achieve greater efficacy by targeting multiple sites in the body. Several GKAs are now in human clinical trials. Results from these trials will determine whether they can distinguish themselves from the widely prescribed sulfonylureas, which are associated with increased mortality [46] as a result of raised cardiovascular risk [47] and may accelerate beta cell apoptosis and exhaustion [48, 49].

Acknowledgements We are grateful to F. Naud of Solvias (Basel, Switzerland) for the synthesis of PSN-GK1 and to Gattefossé (Gennevilliers, France) for generously supplying us with Gelucire 44/14. The MIN6 cells were kindly supplied by J. Miyazaki of Osaka University Graduate School of Medicine, Osaka, Japan. We also acknowledge M. Cawthorne, M. Sennitt and D. Hislop from Buckingham University for in vivo pharmacology experiments, as well as L. Bertram, C. Rasamison, V. Shah and G. Williams from (OSI)Prosidion (Oxford, UK) for technical support. The following are thanked for helpful discussion: K. Lindhardt and M. Thomsen from (OSI)Prosidion, R. Burcelin from University Paul Sabatier (Toulouse, France) and A. Cherrington and D. Granner from Vanderbilt University School of Medicine, USA.

Duality of interest E. Wargent, R. L. Printz and T. Sulpice conducted studies on a fee-for-service basis. M. C. T. Fyfe, J. R. White, A. Taylor, R. Chatfield, M. J. Procter, C. Reynet, J. G. McCormack, P. S. Widdowson and P. Wong-Kai-In are all employed by (OSI)Prosidion and own stock or have stock options in (OSI) Pharmaceuticals (Melville, NY, USA).

\section{References}

1. Gershell L (2005) Type 2 diabetes market. Nature Rev Drug Discov 4:367-368

2. Bell DSH (2004) A comparison of agents used to manage type 2 diabetes mellitus: need for reappraisal of traditional approaches. Treat Endocrinol 3:67-76

3. Wagman AS, Nuss JM (2001) Current therapies and emerging targets for the treatment of diabetes. Curr Pharmaceut Design $7: 417-450$

4. Kietzmann T, Ganjam GK (2005) Glucokinase: old enzyme, new target. Expert Opin Therap Patents 15:705-713

5. Printz RL, Granner DK (2005) Tweaking the glucose sensor: adjusting glucokinase activity with activator compounds. Endocrinology 146:3693-3695

6. Magnuson MA, Matschinsky FM (2004) Glucokinase as a glucose sensor: past, present, and future. In: Matschinsky FM,
Magnuson MA (eds) Glucokinase and glycemic disease: from basics to novel therapeutics. Karger, Basel, pp 1-17

7. Matschinsky FM, Magnuson MA, Zelent D et al (2006) The network of glucokinase-expressing cells in glucose homeostasis and the potential of glucokinase activators for diabetes therapy. Diabetes 55:1-12

8. Baltrusch S, Tiedge M (2006) Glucokinase regulatory network in pancreatic $\beta$-cells and liver. Diabetes 55(Suppl 2):S55-S64

9. Kang L, Dunn-Meynell AA, Routh VH et al (2006) Glucokinase is a critical regulator of ventromedial hypothalamic neuronal glucosensing. Diabetes 55:412-420

10. Theodorakis MJ, Carlson O, Michopoulos S et al (2006) Human duodenal enteroendocrine cells: source of both incretin peptides, GLP-1 and GIP. Am J Physiol Endocrinol Metab 290:E550-E559

11. Zelent D, Golson ML, Koeberlein B et al (2006) A glucose sensor role for glucokinase in anterior pituitary cells. Diabetes 55:19231929

12. Velho G, Froguel P, Gloyn A, Hattersley A (2004) Maturity onset diabetes of the young type 2. In: Matschinsky FM, Magnuson MA (eds) Glucokinase and glycemic disease: from basics to novel therapeutics. Karger, Basel, pp 42-64

13. Sagen JV, Odili S, Bjørkhaug L et al (2006) From clinicogenetic studies of maturity-onset diabetes of the young to unraveling complex mechanisms of glucokinase regulation. Diabetes 55:1713-1722

14. Heredia VV, Carlson TJ, Garcia E, Sun S (2006) Biochemical basis of glucokinase activation and the regulation by glucokinase regulatory protein in naturally occurring mutations. J Biol Chem 281:40201-40207

15. Christesen HBT, Herold K, Noordam K, Gloyn AL (2004) Glucokinase-linked hypoglycemia: Clinical aspects of activating glucokinase mutations. In: Matschinsky FM, Magnuson MA (eds) Glucokinase and glycemic disease: from basics to novel therapeutics. Karger, Basel, pp 75-91

16. Al-Hasani H, Tschöp MH, Cushman SW (2003) Two birds with one stone: Novel glucokinase activator stimulates glucose-induced pancreatic insulin secretion and augments hepatic glucose metabolism. Mol Interventions 3:367-370

17. Leighton B, Atkinson A, Coghlan MP (2005) Small molecule glucokinase activators as novel anti-diabetic agents. Biochem Soc Trans 33:371-374

18. Van Gaal LF, De Leeuw IH (2003) Rationale and options for combination therapy in the treatment of Type 2 diabetes. Diabetologia 46(Suppl 1):M44-M50

19. Guertin KR, Grimsby J (2006) Small molecule glucokinase activators as glucose lowering agents: a new paradigm for diabetes therapy. Curr Med Chem 13:1839-1843

20. Grimsby J, Sarabu R, Corbett WL et al (2003) Allosteric activators of glucokinase: potential role in diabetes therapy. Science 301:370-373

21. Grimsby J, Matschinsky FM, Grippo JF (2004) Discovery and actions of glucokinase activators. In: Matschinsky FM, Magnuson MA (eds) Glucokinase and glycemic disease: from basics to novel therapeutics. Karger, Basel, pp 360-378

22. Efanov AM, Barrett DG, Brenner MB et al (2005) A novel glucokinase activator modulates pancreatic islet and hepatocyte function. Endocrinology 146:3696-3701

23. Sarabu R, Grimsby J (2005) Targeting glucokinase activation for the treatment of type 2 diabetes - a status review. Curr Opin Drug Discov Dev 8:631-637

24. McKerrecher D, Allen JV, Caulkett PWR et al (2006) Design of a potent, soluble glucokinase activator with excellent in vivo efficacy. Bioorg Med Chem Lett 16:2705-2709

25. Futamura M, Hosaka H, Kadotani A et al (2006) An allosteric activator of glucokinase impairs the interaction of glucokinase and glucokinase regulatory protein and regulates glucose metabolism. J Biol Chem 281:37668-37674 
26. Dunten P, Swain A, Kammlott U et al (2004) Crystal structure of human liver glucokinase bound to a small molecule allosteric activator. In: Matschinsky FM, Magnuson MA (eds) Glucokinase and glycemic disease: from basics to novel therapeutics. Karger, Basel, pp 145-154

27. Kamata K, Mitsuya M, Nishimura T, Eiki J-I, Nagata Y (2004) Structural basis for allosteric regulation of the monomeric allosteric enzyme human glucokinase. Structure 12:429-438

28. Fyfe MCT, Gardner LS, Nawano M et al (2004) Tri(cyclo) substituted amide compounds. International Patent Publication WO 2004/072031

29. Fyfe MCT, Naud F (2006) Fluorination process of protected aminothiazole. International Patent Publication WO 2006/016174

30. Yang R, Cao L, Gasa R, Brady MJ, Sherry AD, Newgard CB (2002) Glycogen-targeting subunits and glucokinase differentially affect pathways of glycogen metabolism and their regulation in hepatocytes. J Biol Chem 277:1514-1523

31. Massillon D, Chen W, Hawkins M, Liu R, Barzilai N, Rossetti L (1995) Quantitation of hepatic glucose fluxes and pathways of hepatic glycogen synthesis in conscious mice. Am J Physiol Endocrinol Metab 269:E1037-E1043

32. Perrin C, Knauf C, Burcelin R (2004) Intracerebroventricular infusion of glucose, insulin, and the adenosine monophosphateactivated kinase activator, 5-aminoimidazole-4-carboxamide-1$\beta$-D-ribofuranoside, controls muscle glycogen synthesis. Endocrinology 145:4025-4033

33. Miyazaki J, Araki K, Yamato E et al (1990) Establishment of a pancreatic beta cell line that retains glucose inducible insulin secretion: special reference to expression of glucose transporter isoforms. Endocrinology 127:126-132

34. Leturque A, Brot-Laroche E, Le Gall M, Stolarczyk E, Tobin V (2006) The role of GLUT2 in dietary sugar handling. J Physiol Biochem 61:529-538

35. Tal M, Wu Y, Leiser $\mathrm{M}$ et al (1992) $\left[\mathrm{Val}^{12}\right]$ HRAS downregulates GLUT2 in $\beta$ cells of transgenic mice without affecting glucose homeostasis. Proc Natl Acad Sci U S A 89:5744-5748

36. Agius L (1998) The physiological role of glucokinase binding and translocation in hepatocytes. Adv Enzyme Regul 38: 303-331
37. Zheng Q, Levitsky LL, Mink K, Rhoads DB (1995) Glucose regulation of glucose transporters in cultured adult and fetal hepatocytes. Metabolism 44:1553-1558

38. Veiga-Da-Cunha M, Van Schaftingen E (2002) Identification of fructose 6-phosphate- and fructose 1-phosphate-binding residues in the regulatory protein of glucokinase. J Biol Chem 277:8466-8473

39. Coope GJ, Atkinson AM, Allott C et al (2006) Predictive blood glucose lowering efficacy by glucokinase activators in high fat fed female Zucker rats. Br J Pharmacol 149:328-335

40. Light PE (2002) The ABCs of sulfonylurea receptors, islet $K_{\text {ATP }}$ channels and the control of insulin secretion. Can J Diabetes 26:223-231

41. Brocklehurst KJ, Payne VA, Davies RA et al (2004) Stimulation of hepatocyte glucose metabolism by novel small molecule glucokinase activators. Diabetes 53:535-541

42. Matschinsky FM, Glaser B, Magnuson MA (1998) Pancreatic $\beta$ cell glucokinase: closing the gap between theoretical concepts and experimental realities. Diabetes 47:307-315

43. Zelent D, Najafi H, Odili S et al (2005) Glucokinase and glucose homeostasis: proven concepts and new ideas. Biochem Soc Trans 33:306-310

44. O'Doherty RM, Lehman DL, Telemaque-Potts S, Newgard CB (1999) Metabolic impact of glucokinase overexpression in liver. Lowering of blood glucose in fed rats is accompanied by hyperlipidemia. Diabetes 48:2022-2027

45. Ferre T, Riu E, Franckhauser S, Agudo J, Bosch F (2003) Longterm overexpression of glucokinase in the liver of transgenic mice leads to insulin resistance. Diabetologia 46:1662-1668

46. Simpson SH, Majumdar SR, Tsuyuki RT, Eurich DT, Johnson JA (2006) Dose-response relation between sulfonylurea drugs and mortality in type 2 diabetes mellitus: a population-based cohort study. Can Med Assoc J 174:169-174

47. Bell DSH (2006) Do sulfonylurea drugs increase the risk of cardiac events? Can Med Assoc J 174:185-186

48. Donath MY, Ehses JA, Maedler K et al (2005) Mechanisms of $\beta$ cell death in type 2 diabetes. Diabetes 54(Suppl 2):S108-S113

49. Del Prato S, Pulizzi N (2006) The place of sulfonylureas in the therapy for type 2 diabetes mellitus. Metab Clin Exp 55(Suppl 1): S20-S27 